\title{
Design of a mechanical subcooling system device for increasing a low temperature refrigeration system's capacity
}

\section{Diseño de un dispositivo de subenfriamiento mecánico para aumentar la capacidad de un ciclo de refrigeración de baja temperatura.}

\author{
Juan García-Ibáñez ${ }^{1}$, Guillermo Valencia-Ochoa ${ }^{2}$, Marley Vanegas-Chamorro ${ }^{3}$ \\ ${ }^{1}$ Ingeniero Mecánico, Universidad del Atlántico \\ ${ }^{2}$ Ingeniero Químico, PhD., Profesor Asistente, Universidad del Atlántico \\ ${ }^{3}$ Ingeniero Mecánico, MSc., Profesor Asistente, Universidad del Atlántico \\ Grupo Gestión Eficiente de Energía Kaí. guillermoevalencia@mail.uniatlantico.edu.co
}

Recibido 23/10/13, Aceptado 20/12/2013

\begin{abstract}
The mechanical subcooling is employed to increase the coefficient of performance of any refrigeration cycle, especially in low temperature applications. When is necessary to retrofit a cycle, a dedicated mechanical subcooling system allows great flexibility to find one specific operating point such as a retrofitted system with a mayor capacity and better coefficientof performance (COP) or a retrofitted system with the same capacity and less run time required. Simulations run in Aspen HYSYS® usingthe proper fluid package lets study as many cases needed to get an optimum design for a retrofitted system, taking into account all the restrictions according each component in the main cycle
\end{abstract}

Keywords: Mechanical subcooling, COP, Subcooling temperature, Effectiveness.

\section{RESUMEN}

El subenfriamiento mecánico se emplea para incrementar el coeficiente de desempeño de cualquier ciclo de refrigeración, especialmente en las aplicaciones de baja temperatura. Cuando es necesario reconfigurar un ciclo existente, un dispositivo de subenfriamiento mecánico permite una gran flexibilidad para encontrar un punto específico de operación, ya sea un sistema combinado con un mejor coeficiente de desempeño (COP) y una mayor capacidad de refrigeración o un sistema combinado de la misma capacidad que trabaja por menos tiempo y un mejor COP. Las simulaciones corridas en Aspen HYSYS® permiten estudiar tantos casos posibles como pueden presentarse para lograr un diseño óptimo en el sistema reconfigurado, teniendo en cuenta la restricciones que representan cada uno de los componentes existentes en el sistema principal.

Palabras clave: Subenfriamiento mecánico, COP, temperatura de subenfriamiento, efectividad.

\section{INTRODUCTION}

The mechanical subcooling allows increasing the coefficient of performance of any refrigeration system by establishing a specific subcooling temperature, to retrofit a system is necessary to have a complete comprehension about its the operational context and some technical factors which must be taken into account to reach an optimum design.

Thornton et al. [1] found the most important factor is the subcooling temperature, by proposing an ideal tempera- ture dependent model, which shows the COP's behavior when the subcooling temperature varies between the evaporation and condensation temperature, then with a thermodynamic properties dependent model confirmed the good accuracy of the model.

Khan and Zubair [2,3] developed a model which takes into account all the system's operational characteristics and irreversibility, showing the same behavior found by Thornton et al. [1]. Also simplify the analysis by introducing the effectiveness concept to set the energy balances. 
Qureshi and Zubair [4] studied the effect of refrigerant combinations on performance of a vapor compression refrigeration system with dedicated mechanical subcooling and theyfound R134a has the highest level of performance in this kind of systems.

To find a suitable model to predict the retrofitted cycle's behavior is necessary to establish considerations for the main cycle components.Ding [5] showed a very useful description about the main parameters which have to be taken into account for any component of the refrigeration cycle to develop a right study of the general cycle performance.

Some advantages to provided subcooling to any refrigeration cycle are exposed by Benouali et al. [6] where the study was realized with different subcooling ways, and always the subcooling represent at least capacity increasing.

\section{METHODOLOGY AND CYCLE DESCRIPTION}

The cycle is a refrigeration system which works with R-22 as a refrigerant, evaporating at two temperatures levels, mid temperature $\left[0^{\circ} \mathrm{C}\right]$ and low temperature $\left[-30^{\circ} \mathrm{C}\right]$, there are six evaporators for mid temperature and five for low temperature, with a condensation by air process and four ventilators, two compressor racks one for mid temperature and the other one for low temperature as shown in Figure 1.

Figure 1.Original cycle configuration.

Figura1. Configuración original del ciclo.

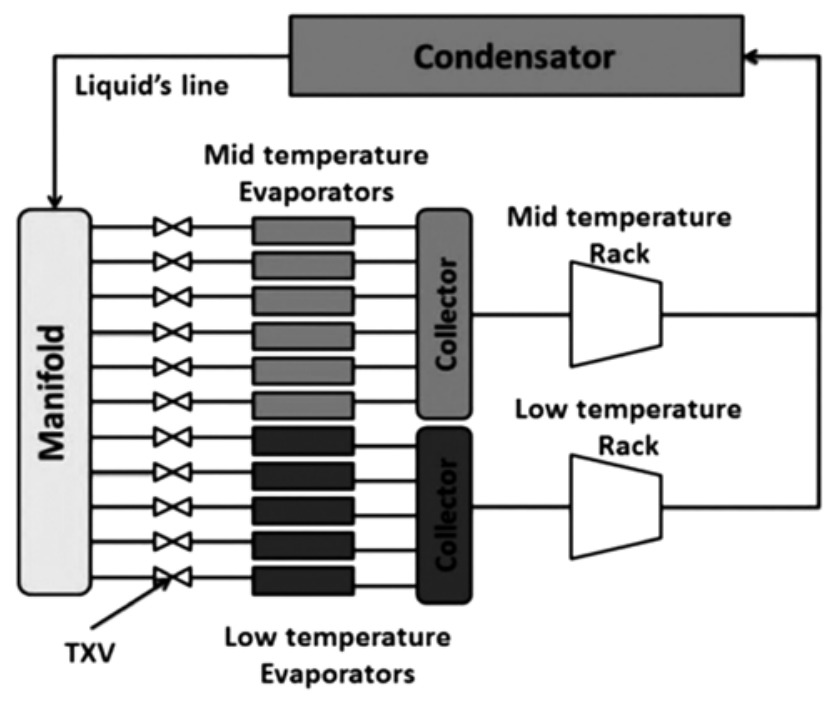

The target is to provide mechanical subcooling to a low temperature system so is necessary modify the current situation by installing two manifold instead of oneas shown in Figure 2.
Figure 2.Necessary retrofit for the cycle.

Figura 2.Adaptación necesaria para el ciclo.

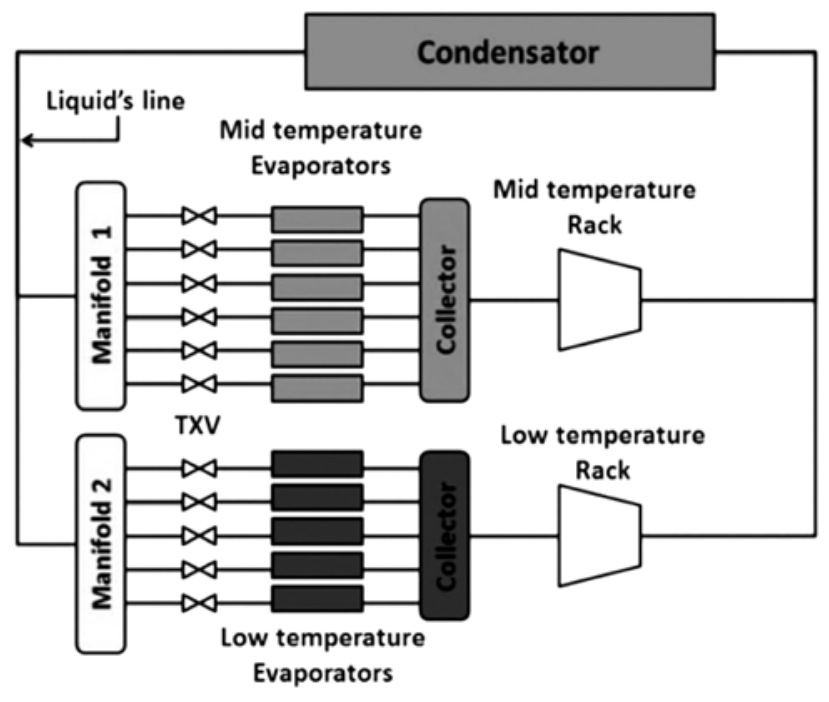

Once the dedicated mechanical subcooling system is installed, the entire system will have the configuration shown in the Figure 3.

Figure 3. Main cycle with dedicated mechanical subcooling. Figura 3. Ciclo principal con subenfriamiento mecánico dedicado.

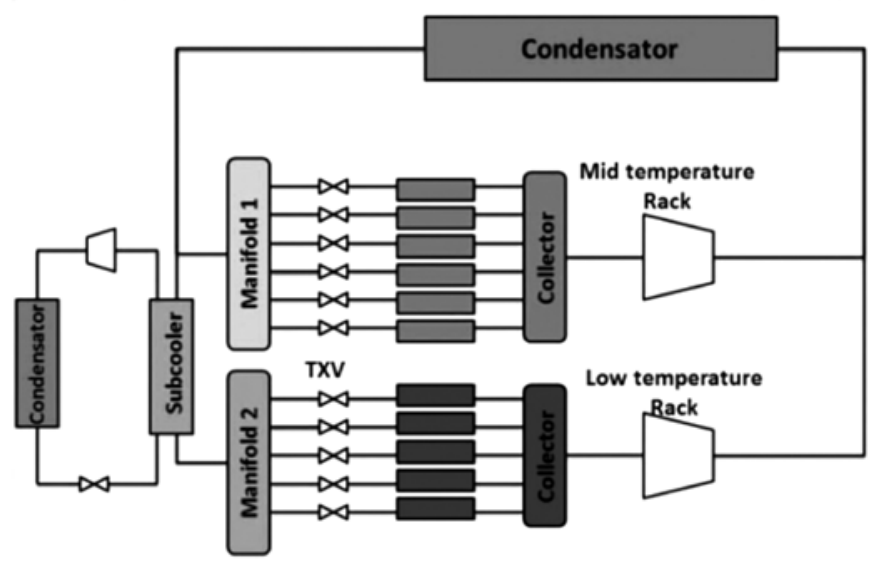

Taking into account that temperature and pressure are intensive properties is possible to simplify the cycle and treat it as a single low temperature refrigeration system with dedicated mechanical subcooling system represented as shown in Figure 4.

The operational conditions for the equivalent law temperature refrigeration cycle such as the average surrounding temperature $\left(\mathrm{T}_{\text {surd }}\right)$, the set point of the evaporator temperature $\left(\mathrm{T}_{\text {target }}\right)$, the motor electrical efficient $\left(\eta_{\text {electrical }}\right)$ and the compressor mechanical efficient $\left(\eta_{\text {mechanical }}\right)$, the discharge 
pressure $\left(\mathrm{P}_{\text {discharge }}\right)$ and suction pressure $\left(\mathrm{P}_{\text {suction }}\right)$ and the compressor operation factor $\left(\mathrm{F}_{\mathrm{op}}\right)$, are summarized in Table 1, which were reported for the maintenance department of a supermarket located in Barranquilla-Colombia.

Figure 4.Simplified cycle.

Figura 4.Ciclo simplificado.

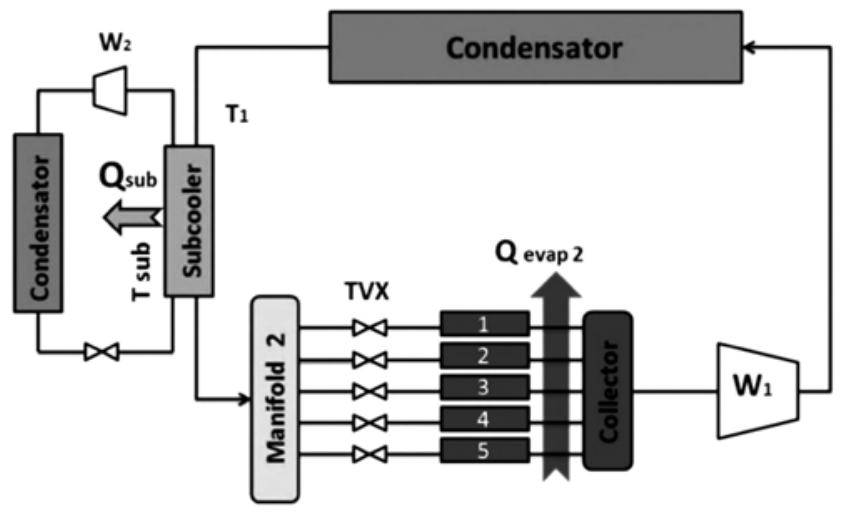

Table 1. Operational parameters

Tabla 1. Parámetros operacionales

\begin{tabular}{|c|c|c|c|}
\hline \multicolumn{4}{|c|}{ Operational parameters } \\
\hline $\mathrm{T}_{\text {surd }}$ & $\mathrm{T}_{\text {target }}$ & $\eta_{\text {electrical }}$ & $\eta_{\text {mechanical }}$ \\
\hline $35^{\circ} \mathrm{C}$ & $-30^{\circ} \mathrm{C}$ & 0.9 & 0.8 \\
\hline $\mathrm{P}_{\text {discharge }}$ & $\mathrm{P}_{\text {suction }}$ & Refrigerant & $\mathrm{FOP}$ \\
\hline 15.5 bar & 0.1 bar & $\mathrm{R}-22$ & 0.85 \\
\hline Refrigeration Capacity & \multicolumn{2}{|c|}{$38 \mathrm{~kW}$} \\
\hline \multicolumn{2}{|c|}{$\mathrm{kW}$} \\
\hline
\end{tabular}

\section{RESULT AND DISCUSSION}

\subsection{Temperature Dependet Model}

The temperature dependent model proposed by Thornton et al. [1], express thecoefficient of performance of the cycle with subcooling $\left(\mathrm{COP}_{\mathrm{cws}}\right)$ depends mainly from the subcooling temperature and the subcooler's effectivenessas follow:

$$
C O P_{c w s}=\frac{\dot{Q}_{\text {evap } 1}+\varepsilon\left(\dot{m} C_{p}\right)_{\min }\left(T_{1}-T_{\text {sub }}\right)}{\dot{W}_{1}+\frac{\varepsilon\left(\dot{m} C_{p}\right)_{\min }\left(T_{1}-T_{\text {sub }}\right)^{2}}{T_{\text {sub }}}},
$$

where:

$\mathrm{COP}_{\text {cws }}$ is the coefficient of performance of the cycle with subcooling.

$\dot{Q}_{\text {evap } 1}$ is the initial refrigeration capacity of the cycle.

$\varepsilon \quad$ is the subcooler effectiveness.

$T_{\text {sub }} \quad$ is the subcooling temperature.

$T_{1} \quad$ is the subcooler inlet refrigerant temperature in the main cycle.

$\dot{m} C_{p}:$ is the heat capacity rate of cold fluid.

$\dot{W}_{1}: \quad$ is the initial compressor energy consumption.
Only $\mathrm{T}_{\text {sub }}$ and $\varepsilon$ are unknown parameters but $\varepsilon$ remains constant once the subcooler heat exchanger is chosen; attending to the above consideration is possible to study the COPcws 's behavior when the $\mathrm{T}_{\text {sub }}$ varies while keeping $\varepsilon$ constant.

\subsection{System's behaviour acording to the temperature dependent model}

Is important to remark the $\mathrm{COP}_{\text {cws }}$ 's tendency do not depend from $\varepsilon$ as can be observed in Figure 5, it means, the effect of $\varepsilon$ is to move the $\mathrm{COP}_{\text {cws }}$ profile. Higher $\varepsilon$ values means higher $\mathrm{COP}_{\mathrm{cws}}$ values at a same subcooling temperature but it shows the same behavior despite the $\varepsilon$ value.

Figure 5. Cop $\mathrm{cws}_{\mathrm{c}}$ as a function of $\mathrm{T}_{\text {sub }}$ in the ideal model. Figura 5. $\mathrm{COP}_{\mathrm{cws}}$ como función de la $\mathrm{T}_{\text {sub }}$ en el modelo ideal.

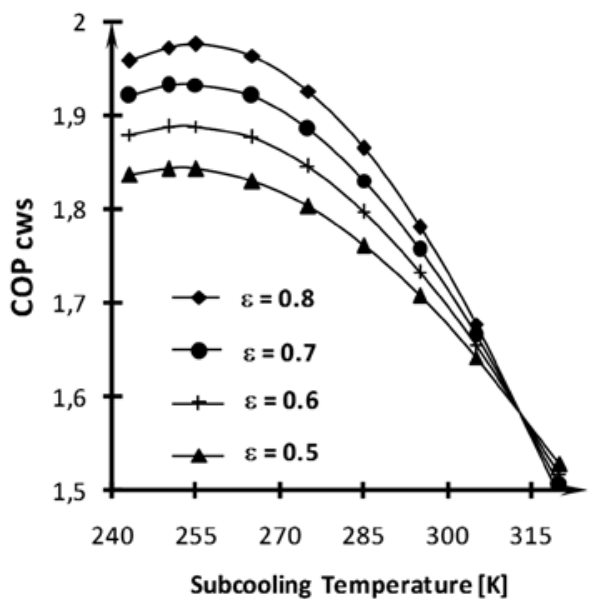

\subsection{Original cycle run in Aspen HYSYS ${ }^{\circledR}$.}

In order to support the results obtained by the temperature dependent model the simplified cycle was run in Aspen HYSYS ${ }^{\circledR}$, according to components shown in Figure 6.

Figure 6. Equivalent cycle.

Figura 6. Ciclo equivalente.

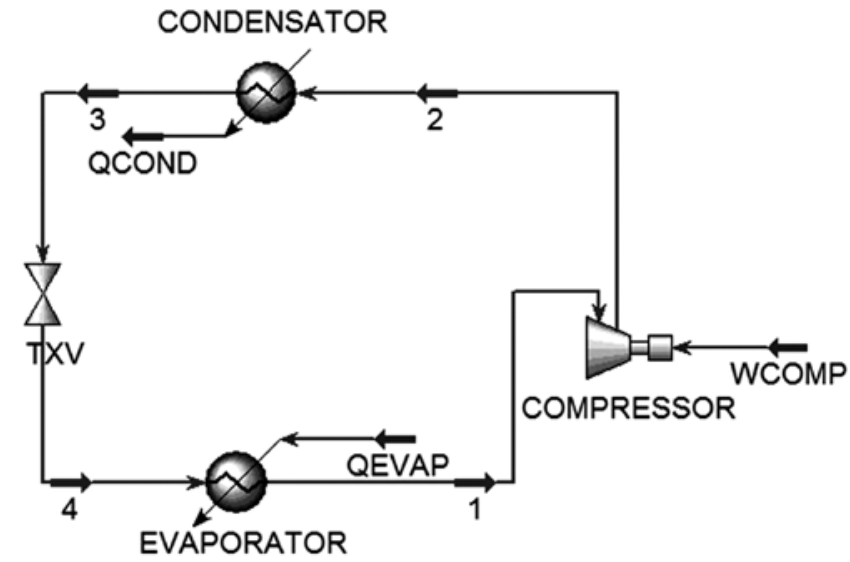


The Table 2 presents the thermodynamic state in the cycle based on the information recovered from the process, assuming saturated vapor at inlet compressor, an adiabatic and polytropicefficient of $75 \%$ and $79.13 \%$ respectly, the mass flow rate was calculated assisted by the software in order to have the power compressor installed on the equipment.

Table 2. Thermodynamic State of the cycle.

Tabla 2. Estado Termodinámico del ciclo.

\begin{tabular}{|c|c|c|c|c|}
\hline \multicolumn{5}{|c|}{ Properties } \\
\hline Flow & $\mathbf{1}$ & $\mathbf{4}$ & $\mathbf{3}$ & $\mathbf{4}$ \\
\hline Pressure[kPa] & 130 & 1596 & 1548 & 164 \\
\hline Temperature[K] & 243.1 & 392,6 & 313.1 & 243.1 \\
\hline Mass Flow[kg/h] & 968 & 968 & 968 & 968 \\
\hline Vapor Fraction & 1 & 1 & 0 & 0,360 \\
\hline COP0 & \multicolumn{5}{|c|}{$\mathbf{5 8 6 0}$} \\
\hline
\end{tabular}

The cycle was simulated in Aspen HYSYS ${ }^{\circledR}$ using the PengRobinson model as Property Packages due to this model havea large applicability range in terms of temperature and pressure, and it was found a COP value of 1.586 while the subcooling temperature is $312 \mathrm{~K}$, which is closed in meaning with the behavior of $\mathrm{COP}_{\mathrm{cws}}$ in Figure 5. Based on the fairly good agreement between the simulation and real behavior on the process, a system's performance study is developed when a dedicated mechanical subcooling is provided using different refrigerants.

\subsection{Dedicated mechanical subcooling cycle with trhee different refrigerants}

The low temperature refrigeration cycle with a dedicated mechanical subcooling system was modeled using Aspen HYSYS $^{\circledR}$ for three different refrigerants on the subcooler cycle. Figure 7 shown a simplified representation of the system as follow:

Figure 7. Simplified cycle with subcooling.

Figura 7. Ciclo sinplificado con subenfriamiento.

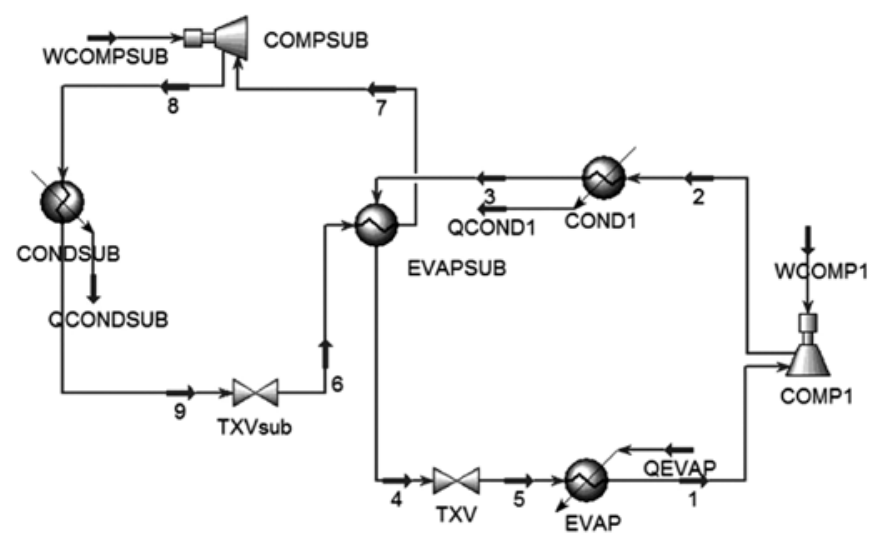

Based on Figure 7, an energy balance is applied to all the cycle, in order to calculate input and output energy transfer. To calculate de $\mathrm{COP}_{\mathrm{cws}}$ a very simple equation is used, this equation takes into account the energy consumption of both compressors and the new system refrigeration capacity, which is the heat transfer removed on the evaporator.

$$
C O P_{c w s}=\frac{\dot{Q}_{\text {evap } 2}}{\dot{W}_{2}}=\frac{\dot{Q}_{\text {evap } 1}+\dot{Q}_{\text {sub }}}{\dot{W}_{1}+\dot{W}_{\text {sub }}}
$$

where:

$\mathrm{COP}_{\text {cws }}$ is the coefficient of performance of the cycle with subcooling.

$\dot{Q}_{\text {evap1 }}$ is theinitial refrigeration capacity of the cycle.

$\dot{Q}_{\text {evap } 2}$ is the refrigeration capacity of the cycle including subcooling.

$\dot{Q}_{s u b}$ is the heat transfer rate on subcooler heat exchanger

$\dot{W}_{1} \quad$ is the initial compressor energy consumption.

$\dot{W}_{\text {sub }}$ is the compressor energy consumption on the auxiliary cycle.

Figure 8 shown the $\mathrm{COP}_{\text {cws }}$ 's behavior while $\mathrm{T}_{\text {sub }}$ changes for using twoalternative refrigerants:R134a, R404a. These are replacements for refrigerants, e.g. R12 that harm the ozone layer and are part of the increasing worry about their global warming potential due to the greenhouse effect as seen in Kyoto Protocol [7].

Even though these alternative fluids are harmless tothe ozone layer, they can contribute to global warming because of leaks but more so, in an indirect way, through energeticperformance of the refrigeration cycle according to Calm [8] and Sand et al. [9].

Figure 8. $\operatorname{Cop}_{\text {cws }}$ as a function of $\mathrm{T}_{\text {sub }}$ for R-404a, R-134a and R-22 on the auxiliary cycle.

Figura 8. Cop ${ }_{\text {cws }}$ como una función de $\mathrm{T}_{\text {sub }}$ para R-404a, R134a y R-22 en el ciclo auxiliar.

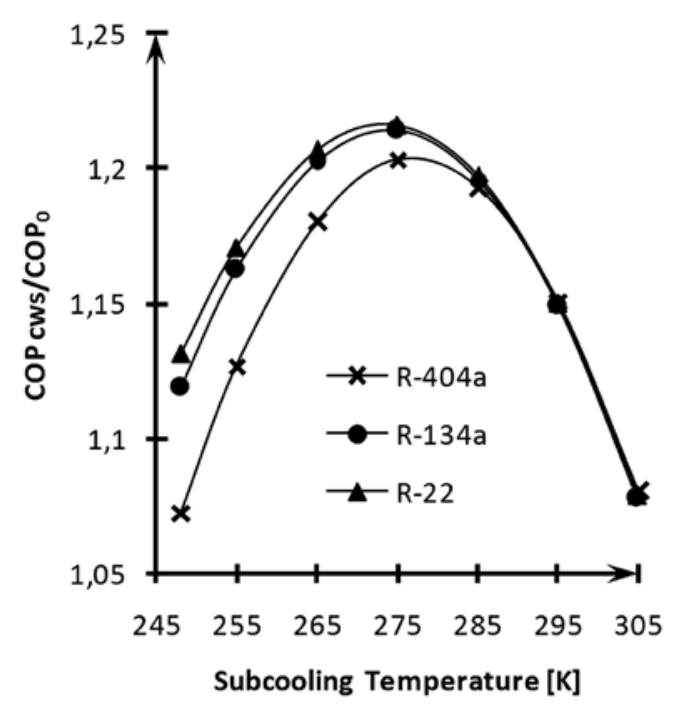


This graphic was developed with $\varepsilon=0.9$, because of a lower subcooler effectiveness the $\mathrm{COP}_{\mathrm{cws}}$ profile for the refrigerants are superimposed in a long temperature range. Figure 9 shows the same tendency as the temperature dependent but the maximum values are displaced to the right as a consequence of the heat transfer and mass flow irreversibilities on the subcooler and the different refrigerant properties, the maximum value reached was $\mathbf{C O P}_{\text {cws }} 1.928$ at $275 \mathrm{~K}$ with R-22. Another way to show the benefits of the mechanical subcooling is comparing the $\mathrm{COP}_{\mathrm{cws}}$ and the initial $\mathrm{COP}_{0}$ for the different refrigerant while $\varepsilon=0.9$ as shown in Figure 9.

Figure 9. $\mathrm{COP}_{\mathrm{cws}} / \mathrm{COP}_{0}$ ratio as a function of $\mathrm{T}_{\mathrm{sub}}$. Figura 9. Relación $\mathrm{COP}_{\mathrm{cws}} / \mathrm{COP}_{0}$ como una función de la $\mathrm{T}_{\text {sub }}$.

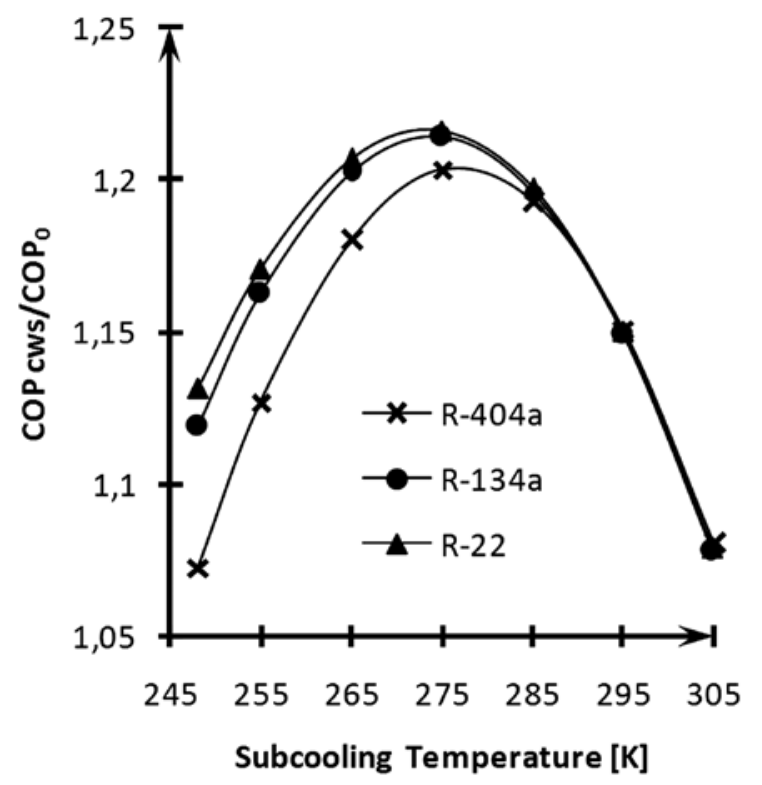

In this case is very easy to see the improvement because the vertical axis shows how much the $\mathrm{COP}_{\mathrm{CwS}}$ increase with respect to $\mathrm{COP}_{0}$. In Figure $9 \mathrm{a}$ value of 1,2 means an improvement of $20 \%$ in the coefficient of performance, also it can be seen the R-22 and R-134a performances are almost equal, for that reason and taking into account that $R$ 134a is less harmful to the environment Schwarz[10], this was chosen as working fluid in the dedicated mechanical subcooling cycle.

\subsection{System performance with R-134a as refrigerant in the dedicated cycle.}

Chosen R-134a as the dedicated mechanical subcooling system refrigerant, the performance for three different values of $\varepsilon$ was studied as shown in Figure 10.
Figure 10. $\mathrm{COP}_{\mathrm{cws}}$ as function of $\mathrm{T}_{\text {sub }}$ with $\mathrm{R}-134 \mathrm{a}$ as refrigerant on the auxiliar cycle.

Figura 10. $\mathrm{COP}_{\mathrm{cws}}$ en función de $\mathrm{T}_{\text {sub }}$ con R-134a como refrigerante en el ciclo auxiliar.

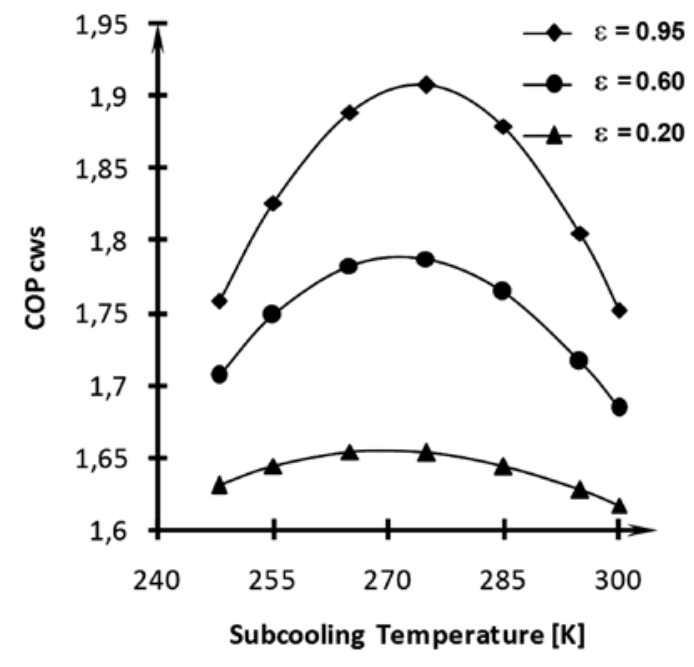

This figure remarks how important is the $\varepsilon$ value to get a technical and economic viability for the dedicated mechanical subcooling system, due tothe subcooling heat exchanger cost depend of $\varepsilon$ value, but is no enough to choose a heat exchanger with a high $\varepsilon$ because of is also important provide the right mass flow in order to exchange as much heat as the $\varepsilon$ value allows, according toresults presented in Figure 11 , when the $\mathrm{COP}_{\mathrm{cws}}$ 's and the mass flow behaviordepends of the outlet refrigerant temperature from the subcooler heat exchanger (liquid line temperature) at the primary cycle side change from $273 \mathrm{~K}$ to $313 \mathrm{~K}$, once $\mathrm{T}_{\text {sub }}$ and $\varepsilon$ have been stated.

Figure 11. Effectiveness and mass flow as function as liquid line temperature.

Figura 11. Eficacia y flujo másicoen función de la temperatura de línea líquida.

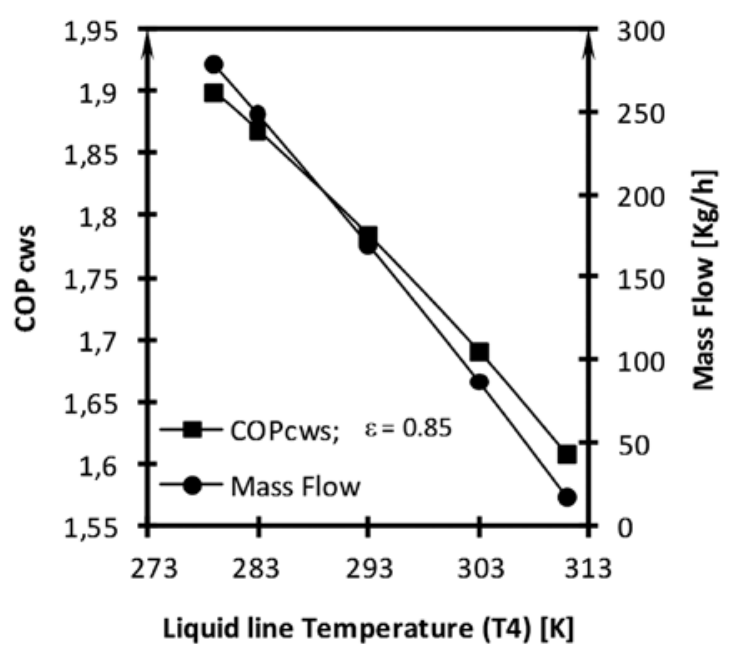


It can be seen that a good $\varepsilon$ value is really important when it work with the proper refrigerant's mass flow, even the electric work consumed by the compressor is proportional to the mass flow Cengel and Boles [11], the overall performance depends on the liquid line temperature after the subcooler, increasing this temperature,reaches the limits that affect the cycle operating conditions, which leads to decrease it'scoefficient of performance and as a result it's cooling capacity as shown in Figure 11. In addition, a higher liquid line temperature increase the electricalpower consumption, making it necessary to improve the performance of these equipmentsunder the new design working conditions. The optimal subcooling temperature for this cycle is $275 \mathrm{~K}$, however the goal is to increase the system capacity; this is limited by the evaporators' nominal capacity, the Table 3 shows the evaporators' capacities.

Table 3. Refrigerating capacities per line.

Table 3. Capacidades de refrigeración por línea.

\begin{tabular}{|c|c|}
\hline Lines & Capacity Btu/h \\
\hline Line 7 & 34800 \\
\hline Line 8 & 34800 \\
\hline Line 9 & 14530 \\
\hline Line10 & 13430 \\
\hline Line11 & 32234 \\
\hline Total Btu/h & 129811 \\
\hline Total $\mathrm{kW} / \mathrm{h}$ & 38.05 \\
\hline
\end{tabular}

It was remarked that all the evaporators could be study as one main evaporator since temperature and pressure are intensive properties, so this cycle can be study a traditional cycle with just one evaporator of $40 \mathrm{~kW}$ nominal capacity. As a technical fact every heat exchanger is able to work properly in a rage of $+/-15 \%$ of the nominal capacity, which is $6 \mathrm{~kW}$, so that the maximum capacity that is possible to reach by mechanical subcooling by maintaining the same components in the main cycle is $46 \mathrm{~kW}$.

It is possible to increase the current capacity $20 \%$, which is $7.61 \mathrm{~kW}$ for a total of $45.65 \mathrm{~kW}$, this value set immediately the subcooler's cooling capacity. A simulation of the cycle was developed with an increase of $20 \%$ through a dedicated mechanical subcooling system at $275 \mathrm{~K}$, as shown in Figure 12.

Once the simulation was developed taking into account all the thermodynamic condition, the drops pressures and the energy duty on the systems were calculated obtaining the Table 4.
Figure 12. Simplified cycle with subcooling simulation at optimal subcooling temperature.

Figura 12. Simulación del ciclo simplificado a la temperatura óptima de subenfriamiento.

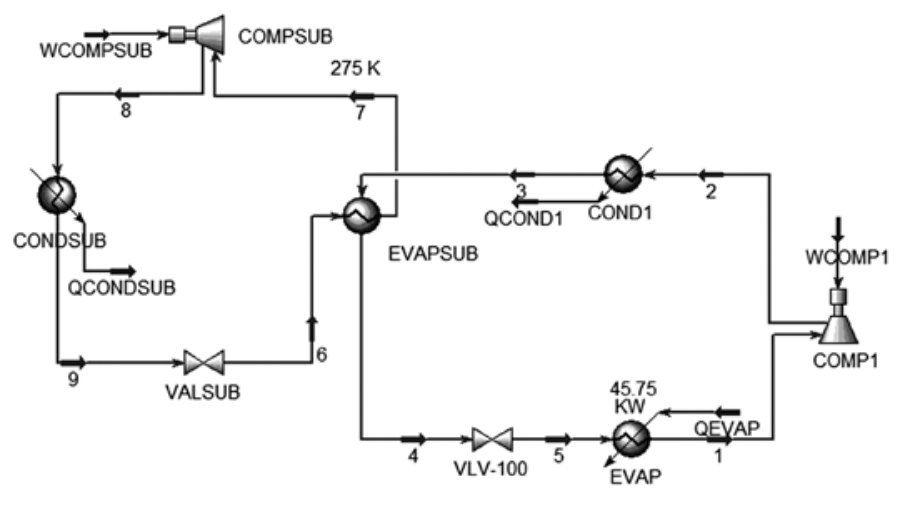

Table 4. Exchagers' main features

Tabla 4. Principales características de los intercambiadores.

\begin{tabular}{|c|c|c|c|c|}
\hline Exchanger & Evap & Cond1 & Condsub & Evapsub \\
\hline Capacity $[\mathrm{kW}]$ & 45.75 & 60.97 & 10 & 7.65 \\
\hline Drop pressure $[\mathrm{kPa}]$ & 34,47 & 48,26 & 13,78 & 0 \\
\hline
\end{tabular}

The compressor' parameters of the simplified cycle are presented in Table 5. It presents the values of power, adiabatic efficiency, polytropic efficiency, change of temperature and pressure, as you can see the compressor number one has greater polytropic efficiency than the subcooling compressor for the optimal operational condition of the overall cycle, information used to select the component for the auxiliary cycle.

Table 5. Compressors' parameters

Tabla 5. Parámetros de los compresores

\begin{tabular}{|l|c|c|}
\hline & Compressor 1 & $\begin{array}{c}\text { Compressor } \\
\text { subcooling }\end{array}$ \\
\hline Power [kW] & 23,57 & 1,63 \\
\hline Adiabatic Efficiency & $75 \%$ & $75 \%$ \\
\hline Polytropic Efficiency & $79,13 \%$ & $76,56 \%$ \\
\hline Delta T [K] & 134,917 & 43,49 \\
\hline Delta P [kPa] & 1429,28 & 597,09 \\
\hline
\end{tabular}

\subsection{Components selection}

All the operational parameters required for any component to achieve the best System's performance are named in Table 6, this information is completely necessary when a component must be chosen. 


\subsubsection{Subcooler evaparorator's selection.}

GEAFlatplate SELECT ${ }^{\mathrm{TM}}$ ONLINE is an informatics application available in internet used to select heat exchanger, allowing user define the operational condition, then the model of the equipment and finally get technical specification useful tool to find the most suitable plate exchanger the following information is required. [12]

Is an internet based Heat Exchanger Selection Program for use by FlatPlate customers on a routine basis. It is an advanced program allowing users to input application design conditions, and then select the appropriate heat exchanger model, including print-outs and drawings.

Table 6. Evaporator and liquid side operational parameter. Tabla 6. Parámetros operacionales evaporador y lado de líquido.

\begin{tabular}{|c|c|c|c|}
\hline \multicolumn{2}{|c|}{ Side A-EVAPORATOR } & \multicolumn{2}{c|}{$\begin{array}{c}\text { Side B - LIQUID } \\
\text { REFRIGERANT }\end{array}$} \\
\hline Refrigerant & $\begin{array}{c}\text { R 134 } \\
\mathrm{a}\end{array}$ & Refrigerant & $\begin{array}{c}\mathrm{R}-22 \\
\text { liquid }\end{array}$ \\
\hline $\begin{array}{c}\text { Evaporation } \\
\text { temperature }\left({ }^{\circ} \mathrm{C}\right)\end{array}$ & 2 & $\begin{array}{c}\text { Entering liquid } \\
\text { temperature }\left({ }^{\circ} \mathrm{C}\right)\end{array}$ & 40 \\
\hline Superheat $\left({ }^{\circ} \mathrm{C}\right)$ & 4 & $\begin{array}{c}\text { Out liquid } \\
\text { temperature }\left({ }^{\circ} \mathrm{C}\right)\end{array}$ & 16 \\
\hline $\begin{array}{c}\text { Liquid temperature } \\
\text { entering to ther- } \\
\text { mostatic expansion } \\
\text { valve(TXV) }\left({ }^{\circ} \mathrm{C}\right)\end{array}$ & 5 & Mass flow $(\mathrm{kg} / \mathrm{h})$ & 950 \\
\hline
\end{tabular}

\subsubsection{Condensator and compressor selection.}

To simplify the installation of a dedicated mechanical subcooling system a condensing unit is recommended to keep the dedicated cycle as small as possible, for this process a software provided by Emerson Climate Technologies[13] was employed. The Table 7 presents all the parameter that must be taken into account for selecting a condensing unit.

Table 7. Compresor's parameters.

Tabla 7. Parámetros del compressor.

\begin{tabular}{|c|c|}
\hline \multicolumn{2}{|c|}{ REQUIRED PARAMETERS TO SELECT } \\
\hline Refrigerant & 134 a \\
\hline Frequency $(\mathrm{Hz})$ & 60 \\
\hline Type of condensation & By air \\
\hline Application temperature & High/medium \\
\hline Environment temperature $\left({ }^{\circ} \mathrm{C}\right)$ & 35 \\
\hline Evaporation temperature $\left({ }^{\circ} \mathrm{C}\right)$ & 2 \\
\hline Condensator duty $(\mathrm{W})$ & 10.200 \\
\hline
\end{tabular}

\subsubsection{Thermostatic expansion valve selection}

The TXV which is the component in the cycle that regulate the amount of refrigerant flow into the evaporator heat exchanger, in this manner controlling the superheating at the outlet of the evaporator.The parameters used to select the TXV are showed in Table 8using the Thermostatic expansion valves catalogue provided byDanfoss[14].

Table 8. Thermostatic expansion valve's parameters.

Tabla 8. Parámetros dela válvula de expansión termostática.

\begin{tabular}{|c|c|}
\hline \multicolumn{2}{|c|}{ THERMOSTATIC EXPANSION VALVE } \\
\hline Refrigerant & $\mathrm{R}-234 \mathrm{a}$ \\
\hline Evaporator duty & $8 \mathrm{KW}$ \\
\hline Evaporation pressure & $3.10 \mathrm{bar}$ \\
\hline Condensation pressure & $10 \mathrm{bar}$ \\
\hline Subcooling & $5^{\circ} \mathrm{C}$ \\
\hline Drop pressure through the TXV & $5.3 \mathrm{bar}$ \\
\hline
\end{tabular}

The simulations was run when all the components' features were input in the model and was possible to estimate an expected $\mathrm{COP}_{\mathrm{cws}}$ for the whole system, working in the conditions the commercial components set.

The operational parameter as well as the $\mathrm{COP}_{\mathrm{cws}}$ was estimated by the simulation, according the thermodynamic states of the subcooler and main cycle, defined by specifying a set of measurable properties sufficient such as the temperature and pressure shownin Tables 9.

Table 9. State properties in the main subcooler cycle.

Tabla 9. Propiedades de estado en el ciclo principal y ciclo subenfriado.

\begin{tabular}{|c|c|c|c|c|c|c|c|c|c|}
\hline \multicolumn{1}{|c|}{ MAIN CYCLE } & \multicolumn{3}{|c|}{ SUBCOOLER CYCLE } \\
\hline Flow & 1 & 2 & 3 & 4 & 5 & 6 & 7 & 8 & 9 \\
\hline Pressure [kPa] & 132,13 & 1596 & 1547 & 1392 & 166 & 483,1 & 317,1 & 1000,1 & 1000 \\
\hline Temperature [ $\left.{ }^{\circ} \mathrm{C}\right]$ & -30 & 118,7 & 40 & 16,4 & -30 & 14,3 & 2 & 49,43 & 35 \\
\hline Mass Flow[kg/h] & 950 & 950 & 950 & 950 & 950 & 198,6 & 198,6 & 198,6 & 198,6 \\
\hline Vapor fraction & 1 & 1 & 0 & 0 & 0,23 & 0,166 & 1 & 1 & 0 \\
\hline
\end{tabular}

Based on the above thermodynamics properties the new overall performancewas calculated, obtaining a COPcws of 1.8125 , which is higher than the initial coefficient of performance for the main cycle. For this reason, the energy consumption can be reduced by incorporating a dedicated mechanicalsub-cooling loop to the existing refrigeration systems.Finally, it is importantto highlight that, for a given system capacity, the totalmaintenance cost for a dedicated mechanical sub-coolingsystem will reduce because 
the systems' head pressure willalways be lower than the conventional cycle according to Qureshi and Zubair [4]. The conclusions of this study is close whit Trottand Welch[15] study, where two possible situations are considerate when a dedicatedmechanical sub-cooling system is applied: developed a completedesign or retrofitting the existing system, using the R134aas working fluid, which isa common substitute for R12 and R22 when the cycle operate at high-temperature level to improve the general coefficient of performance.

\section{CONCLUSIONS}

- A dedicated mechanical subcooling device will increase de original cycle refrigeration capacity and with the proper subcooling temperature also the overall system's COP will be improved. The $\mathrm{COP}_{\mathrm{cws}}$ 's behavior do not depend on the refrigerant's properties because all of the showed the same tendency, but some refrigerants allow to reach higher values of $\mathrm{COP}_{\mathrm{cws}}$ as $\mathrm{R}-22$ and $\mathrm{R}-134 \mathrm{a}$, despite $\mathrm{R}-22$ reach the higher values, $\mathrm{R}-134 \mathrm{a}$ is more friendly with the environment and its performance curve is almost the same as R-22. It is important to remark that the three refrigerants have the same performance when the subcooling temperature is more than $285 \mathrm{~K}$, the increase of the main cycle capacity is limited by the evaporator nominal capacity, the components to build the dedicated mechanical subcooling device are available and very easy to find with the required operational parameters, theses will allow to increase the system capacity in a $20 \%$ and the $\mathrm{COP}_{\mathrm{cws}}$ in $14 \%$ from the original values.

\section{REFERENCIAS}

[1]Thornton,J.W., Klein,S.A., and Mitchell,J.W. Dedicated mechanical subcoolingdesign strategies for supermarket applications. Int. J.Refrig., 17(8), 508- 515,1994.

[2] Khan,J.R.and Zubair,S.M.Design and rating of dedicated mechanicalsubcoolingvapour-compression system. Proc. Inst. Mech. Eng.,214, 455-471, 2000.

[3]. Khan, J-ur-R.andZubair,S.M. Design and rating of an integrated mechanical-subcooling vapor-compression refrigeration system.Energy Convers.Manage., 41, 12011222,2000 .

[4] Qureshi,B.A. andZubair,S.M. The effect of refrigerant combinations on performance of a vapor compression refrigeration system with dedicated mechanical sub-cooling. Int. J.Refrig.,35, 47-57, 2012.
[5] Ding, G.L.Recent developments in simulation techniques for vapour-compression refrigeration systems. Int.J.Refrig., 30, 1119-1133, 2007.

[6]. Benouali, J.,Young, S. and Clodic, D. Analysis of the sub-cooling on refrigerating systemsusing R-410A OR R404A. Eighth International Refrigeration Conference, Purdue University, West Lafayette, USA, 2000.

[7] Kyoto Protocol, Report of the Conference of the Parties.United Nations Framework Convention on Climate Change (UNFCCC) Kyoto, Japan, 1997.

[8] Calm, J.M. Emissions and environmental impacts from airconditioningand refrigeration systems. Int. J. Refrig. 25, 293-305, 2002.

[9] Sand, J.R., Fischer, S.K., and Baxter, V.D., TEWI analysis: its utility, its short comings, and its results. In:International Conference on Atmospheric ProtectionTaipei, Taiwan. 1999.

[10] Schwarz, W. Emission of Refrigerant R-134a from Mobile Air- Conditioning Systems. Study conducted for the German Federal EnvironmentOffice,(Internet). Disponible desde: http://www.umweltbundesamt.de/sites/default/ files/medien/publikation/long/3110.pdf, [Acceso 15octubre 2013].

[11] Cengel, Y. A. and Boles, M. A. Thermodynamics: an engineering approach, 7th edn. McGraw-Hill, New York, 2011.

[12] GEA FlatPlate SELECT ${ }^{\mathrm{TM}}$ - ONLINE. (Internet) On line from: http://flatplateselect.com/site/hx/chooseapp.aspx . [Access January 7th 2013].

[13] Emerson Climate Technologies. (Internet) On line from: http://www.emersonclimate.com/enUS/products/ condensing_units/Pages/condensing_units.aspx. [Access January 7th 2013].

[14] Danfoss. (2010). Technical brochure, Thermostatic expansion valves TUA/TUAE. (Internet). On line from: http://www.ra.danfoss.com/TechnicalInfo/Literature/ Manuals/01/DKRCCPDAG0A302.pdf. [Access October 17th 2013].

[15] Trott, A.R., Welch, T.C. Refrigeration and AirConditioning,third ed. Butterworth-Heinemann, UK, 2000. 